\title{
INTRODUCTION : MISSING
}

\section{Mark Polizzotti}

A feeling of indirection pervades many of Patrick Modiano's writings, and the three short novels in this volume are no exception. For all the specificity of detail-locations catalogued with loving precision, particular casts of light and shadow - one can't escape a sense of haziness, as if everything were shrouded in gauze or viewed through a Vaselined lens. The narrative voice adds to this impression, the protagonists often placing themselves just to the side of the situation they're describing. Like the prose in which they couch their stories, these narrators maintain a slight remove, as if full engagement with one's surroundings carried the threat of great pain, or mortal danger.

Readers familiar with Louis Malle's film Lacombe Lucien (1974), for which Modiano co-wrote the screenplay, will recognize this disengagement: it's the same unconsciousness that lets the title character drift into the world of French fascism, as if by accident. In the novellas included here, a similar diffidence colors the author's efforts in Afterimage to sort out his memories of the photographer Jansen, and the attempts by Patoche, the ten-year-old hero of Suspended Sentences, to penetrate the dubious adult world in which he and his brother live. Even the somewhat more skeptical protagonist of Flowers of Ruin is stymied by his inconclusive pursuit of the elusive Pacheco.

What becomes clear as we read these books is that the inconclusiveness of the pursuit is central to the story-indeed, is the story. Modiano's narrators seem fatally drawn to individuals who are uncommonly vague about themselves and their situation, people whose 
ability to engage the writer's emotional investment - and, one senses, to cause him harm - stands in inverse proportion to the amount of reliable information he's able to garner about them. Each of these novellas turns around a gap, a center that cannot hold: the nebulous Pacheco, the taciturn Jansen (for whom, in turn, the departed Robert Capa and Colette Laurent open a breach), and, for little Patoche, the figure of Annie, she of the bobbed hair, leather jacket, and exotic blue jeans, at once big sister and preadolescent crush, the main actor in a play of bewildering dialogues, entrances, and exits. It's as if each of these figures held the key to a great conundrum, as if they alone could bring everything into focus, but never do. Then again, perhaps this is intentional, for as Modiano confesses elsewhere, "The more obscure and mysterious things remained, the more interested I became in them. I even looked for mystery where there was none."

As befits the wistful undertone of these narratives, their setting is mainly a world gone by. Time and again we're reminded that a particular Parisian building or neighborhood was later razed to make room for something else, or are given a privileged introduction to an obscure nook of the city, usually near the outskirts, that harks back to earlier decades: the Hameau du Danube, the Poterne des Peupliers ... One could easily read these novellas as a three-part love song to a Paris that no longer exists, or that most people's eyes do not see. Despite the action's contemporary setting and the frequent references to bright sunlight, we find ourselves plunged into the atmosphere of Marcel Carné's fog-drenched films, Edith Piaf's smoky laments, and Brassaï's nocturnal photographs. And, fittingly as well, the geography is more often than not the working-class neighborhoods of the city's northern quarters, or Saint-Germain-des-Prés before it became overrun with tourists and new money. The periphery, the zone, the no-man's-land where people stay just outside the law to get by: this is the territory of these novellas.

Few French writers have evoked Paris with as much fondness and nostalgia as Modiano. Baudelaire comes to mind, glowering with dis- 
approval at the newly Haussmannized boulevards as he memorializes the "swarming city, city filled with dreams" (for while "the city scape / Is quick to change, less so the human heart"). So does Aragon, the Paris peasant, conserving the gallerias of the second arrondissement and their alluring, defunct storefronts. Modiano's fictions offer a connoisseur's excavation of the capital, a romance of lost itineraries, such as his detailed re-creation in Flowers of Ruin of Urbain and Giselle T.'s possible routes from Paris to the suburban town of Le Perreux; or the lists - how these books do love lists! — of the sites on which the Jansen of Afterimage trained his camera; or the resurrection, in Suspended Sentences, of the ill-defined "zone where Neuilly, Levallois, and Paris all blended together," whose "streets were wiped off the map when they built the périphérique, taking with them all their garages and their secrets."

Although published separately over a period of five years, the novellas in this volume have remarkable coherence, even if that coherence was unintentional. Modiano's comment for a French omnibus edition of his novels applies just as well here: taken together, he says, those books "form a single work. . . . I thought I'd written them discontinuously, in successive bouts of forgetfulness, but often the same faces, the same names, the same places, the same sentences recur from one to the other."

The resulting impression is of a self-contained world in which figures move and evolve but remain fundamentally similar, as if in a less grandiose version of Balzac's Comédie humaine, a less buffoonish commedia dell'arte, or Wes Anderson's ensemble-cast tragicomedies. People reappear at unexpected moments, like those vaguely recognized characters one sees around the neighborhood. Coincidences occur, sometimes remarked upon, sometimes passing unnoticed. It's as if everything in Modiano's books, including the books themselves, were governed by the six proverbial degrees of separation.

Among the recurrences one will find in these pages, there is the 
older woman who shows the preadult narrator some rare kindness (Annie in Sentences, the Danish girl in Flowers), only to be snatched away by someone more age-appropriate (often wearing a glen plaid suit). There is Pacheco, the great enigma, who intersects with the mystery of the T.'s in Flowers of Ruin, and who also makes a cameo appearance in the novel Honeymoon (1990). There is the "Rue Lauriston gang" (known to history as the Carlingue), part band of thieves, part Gestapo auxiliary, whitewashing its actions with a false patina of respectability. There is the black marketeer and collaborationist Eddy Pagnon, cryptically associated with Modiano's father. And there is the primal scene of the father's wartime arrest as an undocumented Jew by the French police, his liberation by that same Pagnon before he can be deported to a camp-and, in the background, the moral ambiguities of the Occupation and the indelible stain they have left on French history. This episode, which reappears, with variants, in all three books (though in Afterimage the father's role is played by Jansen), and in several others besides, is one of two central knots in Modiano's writing, like a trauma that can be recounted over and over but never exhausted. The other is the childhood death of his kid brother, Rudy; but of that pivotal event we hear no more than a whisper.

The temptation, when reading Modiano's fictions, is to assume they are slices of autobiography. Understandably so: alongside the repetition of nodal scenes, there are numerous correspondences between the personal histories of his storytellers (named Patrick, or its diminutive Patoche, and born, like him, in 1945) and the known facts of the author's own life. A number of these concordances were made explicit-unless they, too, were more invention - in his 2005 memoir Un pedigree. In it, one finds that Modiano's mother, like that of Patoche in Sentences, was an actress frequently away on tour, and that his father, Albert, like his fictional avatars, lived in the "murky world of secret dealings and the black market, in which he circulated by force of circumstance." (Both Jansen and Pacheco, by age as 
well as evasiveness, could be seen as paternal stand-ins.) The house in which young Patrick and Rudy lived for a while was located at 38 Rue du Docteur-Kurzenne in the suburb of Jouy-en-Josas, and corresponds exactly to the description of the house on "Rue du DocteurDordaine" in Sentences; the real-life Annie who looked after the boys at their mother's request was named Suzanne Bouquerau. There was a Frede (the nickname of a certain Suzanne Baulé) who ran a nightclub, and a Jean D. (Jean Normand, alias Duval) who spent time in jail, and a ruined castle, and a Duvelz or Duveltz, and a Danish girl named Kiki who helped the teenage Modiano when he ran away from school...

Most of all, there is the reality of Albert Modiano's arrest and unexplained release and the disappearance of Modiano's beloved brother, about whom he writes in Un pedigree: "Apart from my brother, Rudy, his death, I think that none of what I'll relate here truly concerns me. I'm writing these pages the way one draws up a report or CV, simply as documentation and to have done with a life that wasn't my own." The father, keeper of heavy secrets that he took to the grave, secrets of which his son can uncover only shards; the brother, vanished prematurely, his death bleaching the author's childhood of its emotional reality: these are the true voids in Modiano's writing, the mystery that remains unsolved, the ghost who cannot be exorcised, of whom all the other fugitives and absentees in his books are but shades.

And still, it is important to remember that these are fictionshowever closely their strands might be woven from Modiano's own past-and it seems apt to quote once more his remarks from the French omnibus edition, in which he characterizes his novels as "a kind of autobiography, but one that is dreamed-up or imaginary. Even the photographs of my parents have become portraits of imaginary characters. Only my brother, my wife, and my daughters are real." As for the other figures who lend their presence to these pages, "I used their shadows and especially their names because of the sound; for me, they were nothing more than musical notes." 
With these notes, Modiano has composed a haunting trilogy of love and loss, pitch-perfect in its quiet determination to elucidate the riddles of human identity. Writing, at its best, is a process of discovery, a way of both piercing and preserving a mystery that, by nature, cannot be clarified. Looking back on his attempts to discover the truth about Pacheco, the evidence he has scrupulously compiled, the narrator of Flowers of Ruin reflects: "Without fully realizing it, I began writing my first book. It was neither a vocation nor a particular gift that pushed me to write, but quite simply the enigma posed by a man I had no chance of finding again, and by all those questions that would never have an answer."

\section{Note on the Translation}

Generally speaking, and despite the ambiguities in his narrative strategy, Modiano's prose style is straightforward and clear-by which I do not mean simple - and I have aimed above all to preserve that limpid quality in this translation. His titles are another matter. While a direct translation worked perfectly well for Flowers of Ruin (Fleurs de ruine), and even allowed me to retain the whiff of Baudelairean spleen, this was not the case with Remise de peine-literally, a stay of sentence, but also a deferral of pain. By titling the English version Suspended Sentences, I hope to have kept both the sense of punishment delayed and the dual resonance by introducing a hint of the writer that young Patoche will eventually become.

Chien de printemps required the most liberty. The title-literally "dog of spring," figuratively an expletive along the lines of "rotten spring" or "miserable spring” - refers to Jansen's exclamation ("Goddamn spring"), but also to the actual dog that appears at the end of the book and to the season in which the action occurs. More allusively, the "dog in spring" could be the protagonist himself, sniffing after Jansen to learn his secrets, listless like an abandoned pet after the photographer's departure. One possibility that occurred to me was "bitch 
of a spring," but this neither captured the tone of the relationship nor was a convincing expletive (or, for that matter, a good title). The "dog days" fall in the wrong season, and plays on the word "hound" just seemed silly. Ultimately I decided to forgo the original altogether and concentrate on what this novella seemed most to be about: a retrospective attempt to see, an exercise in hindsight, an afterimage. 
This page intentionally left blank 